\title{
Exogenously applied nitrogenous fertilizers and effective microorganisms improve plant growth of stevia (Stevia rebaudiana Bertoni) and soil fertility
}

\author{
Mohamed Ahmed Youssef ${ }^{1 *}$, Ahmed Fathy Yousef ${ }^{2,3}$, Muhammad Moaaz Ali ${ }^{3}$, Alshaymaa I. Ahmed ${ }^{4}$, \\ Sobhi F. Lamlom ${ }^{5}$, Wacław Roman Strobel ${ }^{6}$ and Hazem M. Kalaji ${ }^{7^{*}}$ (d)
}

\begin{abstract}
The effects of different fertilizers and biofertilizers on crop production to increase plant growth, improve quality and yield components (dry leaves yield, leaf protein, and stevioside) of crops has been extensively studied. However, the combination of both types of fertilizers have rarely been investigated. To explore the effect of different fertilizers and biofertilizers on stevia plant, a two-year field experiment was conducted to investigate the growth response of stevia plants under the influence of nitrogenous fertilizers (NFs) and effective microorganisms (EM). The experiment was laid out in a split-plot design, with EM as the main plot factor (-EM and +EM) and NFs as the subplot factor [control, chemical NFs (Ch-N) and organic NFs (Org-N)]. The results showed that, plants treated with EM and Org-N showed 2-, 2.2-, 2.4-, 2.5-, 3.3- and 3-fold increases in plant height, number of branches, total leaf area, plant fresh weight, plant dry weight and leaf dry yield, respectively, compared to untreated plants. Similarly, plants receiving EM along with Ch-N showed 1.86-, 1.7-, 2.2-, 2.12-, 3-, and 2.72-fold increases in the same traits. Total chlorophyll, protein, N, P, K and sativoside contents were increased by $88.8,152,138,151.5,43$ and $137.5 \%$ when EM and Org-N were applied to stevia plants. Application of EM together with Ch-N increased these properties by $0.5,127.7,115,216,42.6$ and 83.8\%, respectively in the same traits. Overall, the combined application of NFs and EM improved growth, yield and nutrient accumulation in stevia plants.
\end{abstract}

Keywords: Stevioside, Nitrogen recovery efficiency (NRE), HPLC, Soybean protein isolate, Biofertilizer

\section{Introduction}

Stevia (Stevia rebaudiana Bertoni) is one of nearly 300 plant species belonging to the genus Stevia present all over the world, is known as the sweetest plant, sweet leaf, honey yerba, etc. It was originated from South America, officially discovered by Bertoni in 1905, belonging to the Asteraceae family (Das et al. 2007; Zaman et al. 2015b).

\footnotetext{
*Correspondence: Dr_mayoussef@azhar.edu.eg; hazem@kalaji.pl

1 Department of Soils and Water Sciences, Faculty of Agriculture, Al-Azhar University (Assiut Branch), Assiut 71524, Egypt

7 Department of Plant Physiology, Institute of Biology, Warsaw, University of Life Sciences SGGW, 159 Nowoursynowska 159, 02-776 Warsaw, Poland Full list of author information is available at the end of the article
}

Currently, the plant is cultivated in several countries including Japan, China, India, Korea, Taiwan, Philippines, Russia, Tanzania, Indonesia, Hawaii, Canada, Malaysia and Egypt (Rios and Recio 2005). It has become a popular natural source of high potency sweetener, dietary supplement and pharmaceutical products. For this reason, it has a significant impact on the economy of many countries (Debnath 2007; Huda et al. 2007; Zaman et al. 2015c).

The sweetness obtained from Stevia is 100 to 300 times sweeter than sucrose sugar which is extracted from sugar cane and sugar beet (Lemus-Mondaca et al. 2012). It has numerous health benefits against diabetes, hypertension, obesity, cancer, oxidative stress, and microbial infections 
(Ghanta et al. 2007). It is safe for diabetics and hypoglycemics being a healthy and natural sweetener (Ahmad et al. 2020; Kumar et al. 2013). Therefore, stevia represents a crop gaining much popularity among all types of sweeteners as a source of intensively sweet-tasting compounds, i.e., the steviol-glycosides. Stevia leaves contain steviol-glycosides mainly stevioside, rebaudioside $\mathrm{A}$, rebaudioside $B$, rebaudioside $C$, and rebaudioside $E$, etc., and has not been observed any mutagenic, teratogenic, or carcinogenic effects, indicating it as an ideal substitute of sugar (Pól et al. 2007). Stevioside is one of the active constituents that have the largest share in stevia leaves (5-10\% of dry weight basis) (Chumthong and Detpiratmongkol 2016; Das et al. 2008; Patil 2010).

Recently, researchers have been reported on using alternative nutrients to improve plant growth, development, and productivity under various environmental stresses. Elsheery et al. (2020a) have recommended that a combination of $100 \mathrm{mg} \mathrm{L}^{-1}$ nano-zinc oxide $(\mathrm{nZnO})$ and $150 \mathrm{mg} \mathrm{L}^{-1} \mathrm{~d}$ nano-silicon $(\mathrm{nSi})$ improves mango tree resistance, annual crop load, and fruit quality under salinity conditions. It has been recommended that a combination of $0.30 \%$ humic acid $+600 \mathrm{mg} \cdot \mathrm{L}^{-1}$ boric acid to enhance the withstand environmental stresses and improve annual mango tree productivity and fruit quality (El-Hoseiny et al. 2020). The silicon dioxide (nSiO) showed higher amelioration effects and it can be used alone or in combination with other nanoribbons (zinc oxide, selenium, and graphene) to mitigate chilling stress in sugarcane (Elsheery et al. 2020b).

Stevia, being a vegetatively productive plant mainly needs nitrogen supplementation (Hasnain et al. 2020). Nitrogen is considered as an essential nutrient for foliage growth of plants (Hardjowigeno 2007). It is primarily available in the form of $\mathrm{NO}_{3}{ }^{-}$and $\mathrm{NH}_{4}{ }^{+}$, and plants show a strong preference for $\mathrm{NO}_{3}{ }^{-}$over $\mathrm{NH}_{4}{ }^{+}$ions (Zhou et al. 2011). Sufficient nitrogen in the soil plays a vital role in the formation of chlorophyll for the photosynthesis (Tadesse 2019). Chemical nitrogenous fertilizers are one of the main factors accelerating global warming that may cause some environmental problems, such as harmful algal bloom, loss of aquatic life and increasing gas nitrous oxides (Savci 2012; Sedlacek et al. 2020). Though, most of the organic nitrogenous fertilizers are more available and eco-friendly, it is necessary to opt them as an alternative source of the chemical nitrogen used in plant nutrition (Bulluck Iii and Ristaino 2002; Naser et al. 2016).

The proper and judicious use of organic nitrogen fertilizer has become essential to meet the nutritional demand of plants and preserve the environment (Leghari et al. 2016). Using biofertilizers is one of the most critical steps in crop production to increase plant growth, improve fruit quality and yield components of crops through the way of various biochemical activities (Yakhin et al. 2017). In recent years, the investigations proved 'soybean protein' as an excellent source of organic matter for plants, especially being rich in nitrogen contents (Anbu and Saranraj 2016). Along with soybean protein, effective microorganisms (EM) can improve soil fertility status (Chumthong and Detpiratmongkol 2016; Das et al. 2008; El-Sirafy et al. 2015; Kumar et al. 2013; Liu et al. 2011; Shalini and Gupta 2010; Yang et al. 2013). EM can increase the availability of soil nutrients through their biological activity and nutrients uptake by plants (AbdelGawad and Youssef 2019; Bargaz et al. 2018; Das et al. 2007, 2008; Meena et al. 2014; Rajasekaran et al. 2015; Saraswati and Sumarno 2008).

Hence, in current study, we not only investigated the individual and combined effect of EM and nitrogenous fertilizers on yet unexplored aspects of stevia plant growth but also segregated treatment-dependent variations in plant vegetative growth, yield, and nutritional attributes of stevia.

The aim of this study was to explore how effective microorganisms and nitrogenous fertilizers differentially regulated various aspects of plant growth and development of stevia plants.

\section{Material and methods}

\section{Experimental site, climate and soil}

A 2-years field experiment was carried out at research station of the "Soils and Water Department, Faculty of Agriculture, Al-Azhar University, (Assuit branch), Assuit governorate, Egypt" (27 $\left.12^{\prime} 16.67^{\prime \prime} \mathrm{N} ; 31^{\circ} 09^{\prime} 36.86^{\prime \prime} \mathrm{E}\right)$. The climate of this area is characterized as very hot and dry in summer and cold in winter (BWh according to Köppen-Geiger climate map) (Beck et al. 2018) (Fig. 1). The initial physicochemical properties of the soil were determined during both seasons according to Carter (1993) (Table 1). Before preparing the soil for cultivation, soil samples were collected from each plot at one depths $(0-30 \mathrm{~cm})$ using a spiral auger of $2.5 \mathrm{~cm}$ diameter. Three sub-samples from each plot were taken to make a composite soil sample per treatment. They were transported to the laboratory, oven-dried at $40{ }^{\circ} \mathrm{C}$ and crushed to pass through a $2 \mathrm{~mm}$ sieve, and then ground to $<60 \mu \mathrm{m}$ for determination of soil organic carbon content (SOC\%), $\mathrm{N}$, P-available $\left(\mathrm{mg} \mathrm{kg}^{-1}\right)$, and $\mathrm{K}$-exchangeable $\left(\mathrm{cmol} \mathrm{kg}{ }^{-1}\right)$ (Madejón et al. 2006). Furthermore, electric conductivity (E.C.) $\left(\mu \mathrm{S} \mathrm{cm}^{-1}\right)$ and soil $\mathrm{pH}$ were estimated through standard procedures as described by Carter (1993).

\section{Experimental design and treatments}

This experiment was laid out in split-plot design having 2 levels of bio stimulant application as main plot [treated with EM (142.8 $\left.\mathrm{L} \mathrm{ha}^{-1}\right)$ vs. untreated plants, 


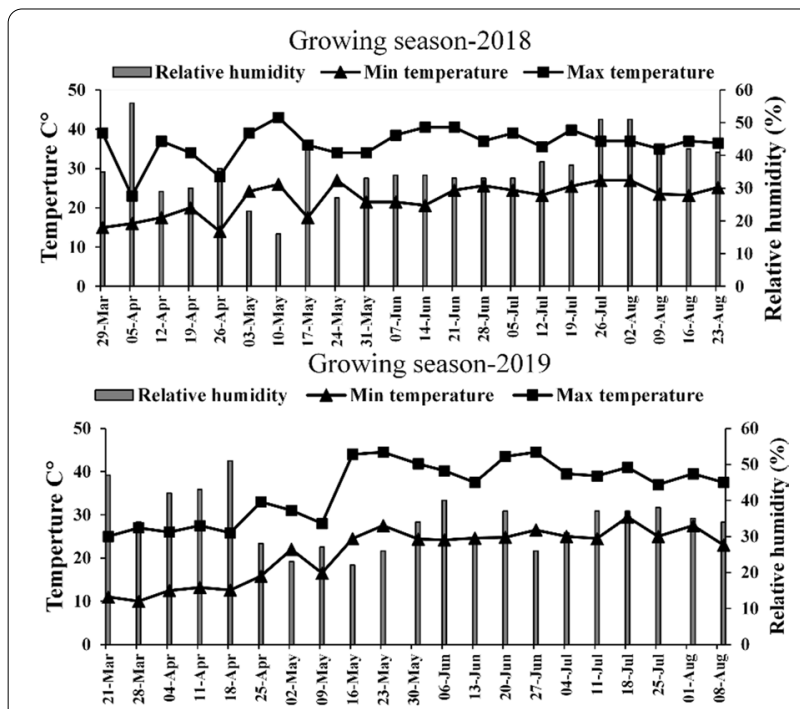

Fig. 1 Weather conditions during the two growing periods of Stevia cultivation

Table 1 Some physical and chemical characteristics of soil experimental

\begin{tabular}{|c|c|c|}
\hline \multirow[t]{2}{*}{ Parameters } & \multicolumn{2}{|l|}{ Values } \\
\hline & 2018 & 2019 \\
\hline \multicolumn{3}{|l|}{ Particle size distribution } \\
\hline Sand (\%) & 46.30 & 49.25 \\
\hline Silt (\%) & 28.40 & 30.43 \\
\hline Clay (\%) & 25.30 & 20.32 \\
\hline Texture grade & Silt clay loam & Silt loam \\
\hline \multicolumn{3}{|l|}{ Available nutrients $\left(\mathrm{mg} \mathrm{kg}^{-1}\right)$} \\
\hline $\mathrm{N}$ & 77.48 & 89.28 \\
\hline$P$ & 30.35 & 35.84 \\
\hline K & 379.32 & 436.53 \\
\hline \multicolumn{3}{|c|}{ Soluble cations and anions (cmol kg soil) } \\
\hline $\mathrm{Ca}^{++}$ & 0.88 & 0.94 \\
\hline $\mathrm{Mg}^{++}$ & 0.69 & 0.75 \\
\hline $\mathrm{Na}^{+}$ & 0.43 & 0.58 \\
\hline $\mathrm{K}^{+}$ & 0.32 & 0.47 \\
\hline $\mathrm{HCO}_{3}^{-}$ & 0.67 & 0.73 \\
\hline $\mathrm{Cl}^{-}$ & 0.53 & 0.66 \\
\hline $\mathrm{SO}_{4}^{--}$ & 0.41 & 0.57 \\
\hline \multicolumn{3}{|l|}{ Chemical properties } \\
\hline pH (Susp. 1:2.5 soil-water) & 8.23 & 7.96 \\
\hline$E C_{e}\left(d S m^{-1}\right)$ & 0.686 & 0.786 \\
\hline C.E.C $\left(\mathrm{cmol} \mathrm{kg}^{-1}\right)$ & 18.76 & 19.38 \\
\hline Organic matter (\%) & 1.38 & 1.73 \\
\hline $\mathrm{CaCO}_{3}(\%)$ & 1.22 & 1.32 \\
\hline
\end{tabular}

Each value in this table is the mean of 4 replicates hereafter EM+ and EM-, respectively], and $2 \mathrm{~N}$ fertilization types as sub-plot [chemical nitrogenous fertilizer $\left(214 \mathrm{~kg} \mathrm{ha}^{-1} \mathrm{~N}\right)$ and organic nitrogenous fertilizer $\left(214 \mathrm{~kg} \mathrm{ha}^{-1} \mathrm{~N}\right)$, hereafter Ch-N and Org-N, respectively] with four replicates. A N-unfertilized control was comparatively introduced in the experiment.

The soil was prepared by plowing twice orthogonally, then flattening the soil and dividing the experimental plots $(4 \times 3 \mathrm{~m})$. Stevia seedlings were transplanted at a spacing of $30 \times 50 \mathrm{~cm}$ (68 plants in each plot) under a drip irrigation system. The seedlings of Stevia rebaudiana Bertoni (Trade Name: Steviatech) were purchased from "Bio Tech Co., Giza, Egypt". The seedlings were transplanted when $15-20 \mathrm{~cm}$ length was acquired (28th and 20th March in 2018 and 2019, respectively). The liquid Bio-fertilizer of EM containing Lactobacillus casei $\left(9 \times 10^{7} \mathrm{cfu}\right)$, Lactococcus lactis $\left(5 \times 10^{7} \mathrm{cfu}\right)$, Saccharomices cerevisiae $\left(2 \times 10^{6} \mathrm{cfu}\right)$, Rhodopseudomonas palustris $\left(4 \times 10^{6}(\mathrm{cfu})\right.$ including photosynthetic bacteria, lactic acid bacteria, and yeast [EMPO, Okinawa 901-2311, Japan (https://www.emrojapan.com)] was obtained from "Agricultural Research Center, Giza, Egypt". Effective Microorganisms (EM) were applied 30, 51, 72, 93, 114, and 135 days after transplanting (DAT) with immersed-way irrigation, the periods between the two waterings were range from $8-15$ days (increased and decreased depending on the temperature). Ammonium nitrate having $33.5 \% \mathrm{~N}$ was used as the source of $\mathrm{Ch}-\mathrm{N}$ and applied in three splits i.e., 30, 72, and 114 DAT. While isolated soybean protein having $15.36 \% \mathrm{~N}$ was applied as Org-N as basal dose. Hand weeding was carried out 48, 69, 90, and 110 DAT in both growing seasons. Chemical composition of isolated soybean protein was analyzed according to Motsara and Roy (2008) and listed in Table 2.

Table 2 Chemical composition of isolated soy protein samples used in the study on dry weight basis

\begin{tabular}{lc}
\hline Determination & values \\
\hline $\mathrm{N}(\%)$ & 15.36 \\
$\mathrm{P}(\%)$ & 1.25 \\
$\mathrm{~K}(\%)$ & 0.12 \\
$\mathrm{pH}($ Susp. 1:10) & 6.46 \\
$\mathrm{EC} \mathrm{dS} / \mathrm{m}($ Ext. 1:10) & 2.715 \\
Organic C (\%) & 38.07 \\
Organic matter (\%) & 65.64 \\
C/N ratio & $2.5: 1$ \\
Bulk density $\left(\mathrm{g} / \mathrm{cm}^{3}\right)$ & 0.36 \\
\hline
\end{tabular}

Each value in this table is the mean of 4 replicates 


\section{Data collection}

Stevia plants were harvested in two cuttings (first cutting was performed 79 and 76 DAT, while second cuting 145 and 138 DAT in 2018 and 2019, respectively), at the stage when plants hold $10 \%$ of the flowers. Six plants from each plot were randomly choosen, and plant growth, yield and nutritional variables were recorded. The height of each plant was measured using meter rod from the soil surface to the top of the plant and number of branches were counted. The fresh weight of each plant was measured using digital weighing balance (MJ-W176P, Panasonic, Japan). Leaves from each plant were separated and weighed using the same digital weighing balance. Leaf area was estimated as described by Pandey and Singh (2011) For dry weight determination, plants were ovendried at $65{ }^{\circ} \mathrm{C}$ until constant dry mass was attained (Sorgonà et al. 2011).

Before chemical analysis, the twenty leaves from the top were collected and washed three times with distilled water.. According to Motsara and Roy (2008), the nitrogen content of leaves was measured using the Kjeldahl apparatus. Phosphorus contents were determined using JENWAY $6305 \mathrm{UV} /$ Visible Spectrophotometer at $643 \mathrm{~nm}$ (OD643) by the colorimeter method (ammonium molybdate) (Motsara and Roy 2008). Potassium contents in leaves were determined using a Flame Photometer (BWB Model BWB-XP, 5 Channel) as described by Motsara and Roy (2008). Protein content in leaves (expressed on a percentage basis) was calculated as $\mathrm{N}$ content $(\%) \times 6.25$ (Mariotti et al. 2008). Chlorophyll contents from fully developed leaves were determined using a mobile chlorophyll meter (SPAD-502-m Konica Minolta, Inc., Tokyo, Japan). The performance of the chlorophyll meter was calibrated according to the manufacturer's instructions, before taking the readings. The stevioside contents were estimated through High-Performance Liquid Chromatography (HPLC) following the protocol of Nishiyama et al. (1992).

\section{Statistical analysis}

Collected data were subjected to a split-plot analysis of variance (ANOVA) using SPSS statistical software package version 16.0 (SPSS Inc., Chicago, IL, USA). Significant differences between treatment means were executed using Fisher's least significant difference (LSD) test, when level of significance was $5 \%(p \leq 0.05)$.

\section{Results}

Plant height, number of branches, leaf area, plant fresh weight, plant dry weight and dry leaves yield

In first season (2018), the plants receiving EM exhibited better plant height $(48.55 \mathrm{~cm})$, number of branches per plant (34.44), leaves area per plant $\left(1093.64 \mathrm{~cm}^{2}\right)$, plant fresh weight $(93.75 \mathrm{~g})$, plant dry weight $(24.69 \mathrm{~g})$, and leaf dry yield $\left(669.23 \mathrm{~kg} \mathrm{ha}^{-1}\right)$ as compared to untreated plants. Among nitrogenous fertilizers treatments, the plants treated with Org-N showed better plant height $(56.58 \mathrm{~cm})$, number of branches per plant (41.83), plant fresh weight $(117.22 \mathrm{~g})$, plant dry weight $(31.43 \mathrm{~g})$, leaves area per plant $\left(1305.9 \mathrm{~cm}^{2}\right)$ and dry leaves yield $\left(859.58 \mathrm{~kg} \mathrm{ha}^{-1}\right)$ as compared to untreated plants and those treated with $\mathrm{Ch}-\mathrm{N}$. Considering the combined effect of EM and NFs, the highest values of same attributes $\left(59.50 \mathrm{~cm}, 43.33\right.$ plant $^{-1}, 119.86 \mathrm{~g}, 32.96 \mathrm{~g}, 1335.27$ $\mathrm{cm}^{2}$ and $17.39 \mathrm{~g}$, respectively) were recorded in the plants provided with Org-N along with EM. Similarly, in second growing season (2019), the plants receiving EM exhibited 1.09, 1.09, 1.04, 1.09, 1.14, and 1.11-fold increase in plant height, number of branches, leaves area per plant, plant fresh weight, plant dry weight, and leaves dry yield as compared to untreated plants, respectively. Among nitrogenous fertilizers treatments, the plants treated with Org-N, being best treatment showed 2.04, 2.28, $1.97,2.13,3.14$, and 3.05 -fold increase in same attributes as compared to untreated plants and those treated with Ch-N. Considering the combined effect of EM and NFs, the plant height, number of branches, leaves area per plant, plant fresh weight, plant dry weight, and leaves dry yield were increased by $112.45,152.97,110.88,142.74$, 265.38 and $243.60 \%$, respectively, when EM and Org-N were applied to stevia plants. While, by the application of EM along with Ch-N, these attributes were enhanced by $93.77,88,99,88.77,226.73$ and $209.87 \%$, respectively (Tables 3, 4).

\section{Leaf nitrogen, phosphorus, and potassium}

In both growing seasons, the maximum leaf nitrogen and potassium were recorded in the plants receiving Org-N along with EM, followed by the plants treated with Org-N without EM as compared to control. On the other hand, maximum phosphorus contents were recorded in the plants treated with $\mathrm{Ch}-\mathrm{N}$ fertilizer, regardless of EM application. While the lowest average values for all observed nutritional attributes (N, P and K content) were observed in untreated plants during both growing seasons (Fig. 2).

\section{Leaf chlorophyll}

In both growing seasons, the plants treated with Org-N exhibited maximum leaf chlorophyll contents (4.72 and $5.14 \mathrm{mg} \mathrm{g}^{-1} \mathrm{FW}$ in 2018 and 2019, respectively) among all other treatments. Effective microorganisms could not influence the chlorophyll contents significantly $(p \leq 0.05)$. Chemical nitrogen was also proved promising treatment after Org-N (Fig. 3). 
Table 3 Effect of nitrogenous fertilizers and effective microorganism on plant height, number of branches and leaf area of Stevia rebaudiana during two growing seasons

\begin{tabular}{|c|c|c|c|c|c|c|c|c|c|c|}
\hline \multirow[t]{2}{*}{ Growing season } & \multirow[t]{2}{*}{ Treatments } & \multicolumn{3}{|c|}{ Plant height $(\mathrm{cm})$} & \multicolumn{3}{|c|}{ No of branches } & \multicolumn{3}{|c|}{ Leaf area $\left(\mathrm{cm}^{2}\right.$ plant $\left.^{-1}\right)$} \\
\hline & & $\mathrm{EM}(-)$ & $\mathrm{EM}(+)$ & Mean (NFs) & $\mathrm{EM}(-)$ & $\mathrm{EM}(+)$ & Mean (NFs) & $\mathrm{EM}(-)$ & $\mathrm{EM}(+)$ & Mean (NFs) \\
\hline \multirow[t]{4}{*}{2018} & Control & $29.72 \mathrm{e}$ & $33.16 d$ & $31.44 c$ & $23.42 d$ & $24.16 d$ & $23.79 c$ & $498.5 d$ & $720.82 c$ & $609.66 c$ \\
\hline & Ch-N & $46.50 c$ & $53.00 \mathrm{~b}$ & $49.75 b$ & $33.83 c$ & $35.83 c$ & $34.83 b$ & 1195.30b & $1224.84 a b$ & $1210.07 b$ \\
\hline & Org-N & $53.66 b$ & $59.50 \mathrm{a}$ & $56.58 a$ & $40.33 b$ & $43.33 a$ & $41.83 a$ & $1276.53 a b$ & 1335.26a & 1305.9a \\
\hline & Mean (EM) & $43.29 b$ & $48.55 a$ & & $32.53 b$ & $34.44 a$ & & $990.11 b$ & 1093.64a & \\
\hline LSD interaction $(p \leq 0.05)$ & & 2.47 & & & 2.89 & & & 126.42 & & \\
\hline \multirow[t]{4}{*}{2019} & Control & $30.36 d$ & $31.33 d$ & $30.84 c$ & $25.43 f$ & $29.16 e$ & $27.3 c$ & $804.5 c$ & $900.4 c$ & $851.95 c$ \\
\hline & Ch-N & $49.66 c$ & $58.83 b$ & $54.25 b$ & $44.16 d$ & $47.83 c$ & $46 b$ & $1571.68 b$ & 1601.22ab & $1586.45 b$ \\
\hline & Org-N & $61.33 b$ & $64.5 \mathrm{a}$ & $62.91 \mathrm{a}$ & $60.33 b$ & $64.33 a$ & $62.33 a$ & $1657.91 \mathrm{ab}$ & $1696.54 a$ & 1677.23a \\
\hline & Mean (EM) & $47.12 b$ & $51.55 a$ & & $43.31 b$ & $47.11 \mathrm{a}$ & & $1344.36 a$ & 1399.39a & \\
\hline LSD interaction $(p \leq 0.05)$ & & 2.62 & & & 1.814 & & & 124.79 & & \\
\hline
\end{tabular}

The values shown in table are means of two cuttings having four replicates. $E M$ Effective microorganisms (biofertilizer), $C h-N$ Chemical-N form, Org- $N$ Organic- $\mathrm{N}$ form, Means followed by the same letters are non-significantly different $(p \leq 0.05)$

Table 4 Effect of nitrogenous fertilizers and effective microorganisms on plant fresh weight, plant dry weight and dry leaves yield of Stevia rebaudiana during two growing seasons

\begin{tabular}{|c|c|c|c|c|c|c|c|c|c|c|}
\hline \multirow[t]{2}{*}{ Growing season } & \multirow[t]{2}{*}{ Treatments } & \multicolumn{3}{|c|}{ Plant fresh weight (g) } & \multicolumn{3}{|c|}{ Plant dry weight (g) } & \multicolumn{3}{|c|}{ Dry leaves yield $\left(\mathrm{Kg} \mathrm{ha}^{-1}\right)$} \\
\hline & & EM (-) & $\mathrm{EM}(+)$ & Mean (NFs) & EM (-) & $\mathrm{EM}(+)$ & Mean (NFs) & $\mathrm{EM}(-)$ & $\mathrm{EM}(+)$ & Mean (NFs) \\
\hline \multirow[t]{4}{*}{2018} & Control & $44.25 \mathrm{e}$ & $56.85 d$ & $50.55 c$ & $10.86 d$ & $12.45 d$ & $11.65 c$ & $330.88 d$ & $337.62 d$ & $334.25 c$ \\
\hline & Ch-N & $96.88 c$ & $104.56 b$ & $100.72 b$ & $25.64 c$ & $28.68 b$ & $27.16 b$ & $735.64 c$ & $776.08 \mathrm{bc}$ & $755.86 b$ \\
\hline & Org-N & $114.59 a$ & 119.86a & $117.22 \mathrm{a}$ & $29.9 b$ & $32.96 a$ & $31.43 a$ & $825.18 a b$ & $893.98 a$ & $859.58 a$ \\
\hline & Mean (EM) & $85.24 b$ & $93.75 a$ & & $22.13 b$ & $24.69 a$ & & $630.57 a$ & $669.23 a$ & \\
\hline LSD Interaction $(P \leq 0.05)$ & & 5.75 & & & 2.22 & & & 79.79 & & \\
\hline \multirow[t]{4}{*}{2019} & Control & $60.13 e$ & $68.99 d$ & $64.56 c$ & $12.42 d$ & $14.62 d$ & $13.52 \mathrm{c}$ & $355.41 \mathrm{C}$ & $392.81 \mathrm{C}$ & $374.11 \mathrm{c}$ \\
\hline & Ch-N & $110.96 \mathrm{c}$ & $113.51 \mathrm{C}$ & $112.23 b$ & $36.4 c$ & $40.58 b$ & $38.49 b$ & $1018.3 b$ & $1101.33 b$ & $1059.81 b$ \\
\hline & Org-N & $129.05 b$ & 145.96a & $137.51 \mathrm{a}$ & $39.42 b c$ & $45.38 a$ & $42.4 a$ & $1063.37 b$ & 1221.19a & $1142.28 a$ \\
\hline & Mean (EM) & $100.05 b$ & 109.49a & & $29.41 b$ & $33.52 a$ & & $812.36 b$ & $905.11 a$ & \\
\hline LSD Interaction $(P \leq 0.05)$ & & 3.415 & & & 3.43 & & & 86.88 & & \\
\hline
\end{tabular}

The values shown in table are means of two cuttings having four replicates. $E M$ Effective microorganisms (biofertilizer), $C h-N$ Chemical-N form, Org- $N$ Organic- $\mathrm{N}$ form, Means followed by the same letters are non-significantly different $(p \leq 0.05)$

\section{Leaf protein and stevioside content}

During both growing seasons, maximum leaf protein contents (11.62 and $15.49 \%$ in 2018 and 2019, respectively) were recorded in the plants receiving Org-N along with EM. While the lowest values were observed in untreated plants during both growing seasons (Fig. 4a). Similarly, in case of leaf stevioside contents, the plants treated with the combination of Org-N and EM showed maximum performance (9.17 and 9.98\% in 2018 and 2019, respectively). The EM uplifted the average stevioside contents by $23.52 \%$, while Org-N enhanced the contents by $95.35 \%$. On the other hand, the lowest stevioside contents (3.42 and 4.30\% in 2018 and 2019, respectively) were recorded in untreated plants (Fig. 4b).

\section{Post-harvest fertility status of soil}

The chemical properties of soil i.e., EC, soil $\mathrm{pH}, \mathrm{SOC}$, available $\mathrm{N}, \mathrm{P}$, and exchangeable $\mathrm{K}$ were significantly affected by the application of different nitrogenous fertilizers with or without effective microorganisms after stevia plantation (Figs. 5, 6). Under the influence of NFs, soil EC remained unchanged during 2018, while increased during 2019. Maximum EC was recorded as influenced by Org- $\mathrm{N}$ in 2019 . Effective microorganisms significantly enhances soil EC during both growing seasons. Soil pH was reduced as affected by NFs in both growing seasons. Effective microorganism also played a significant role in reducing $\mathrm{pH}$ during 2019. The SOC increased by application NFs, while remained unchanged with EM application during both growing seasons (Fig. 5). During both 

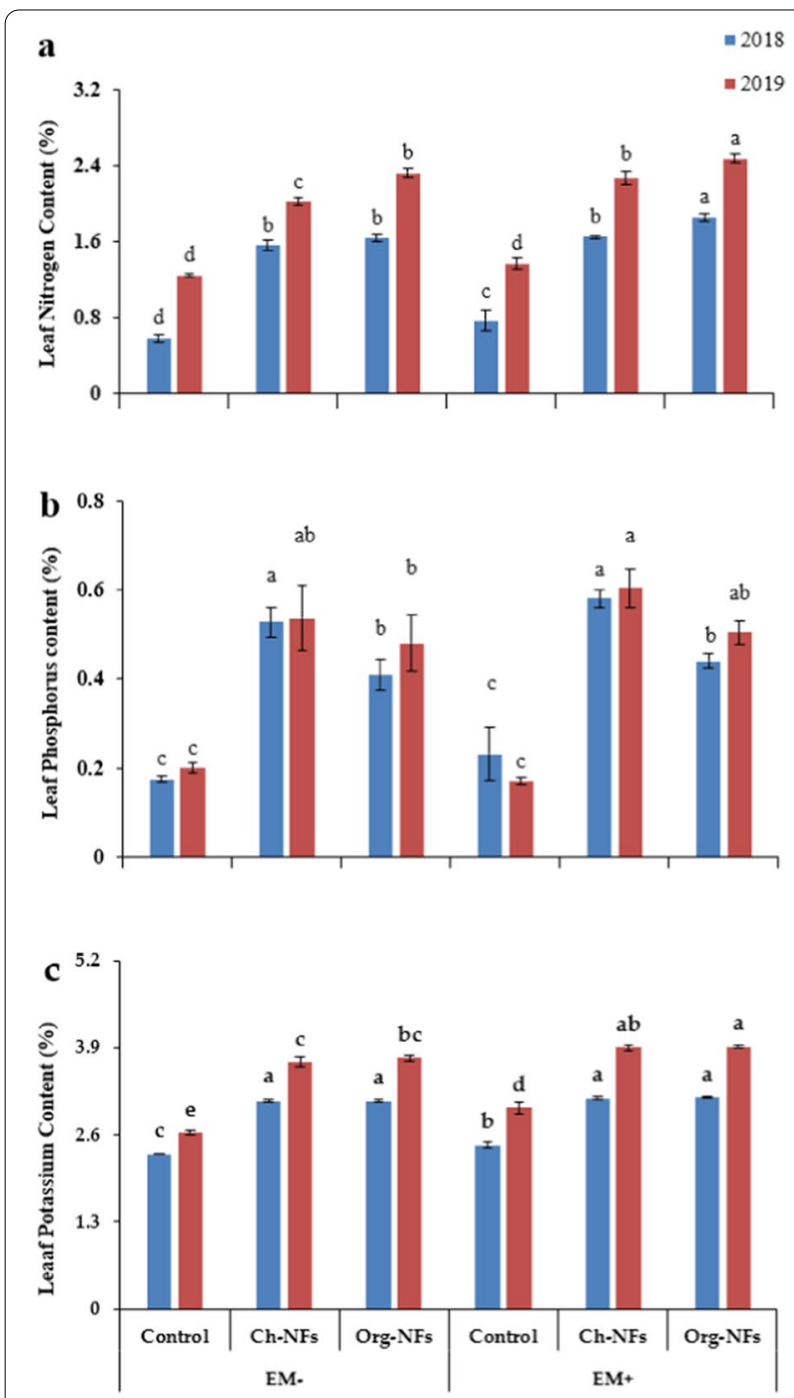

Fig. 2 Effect of nitrogenous fertilizers and effective microorganisms on leaf nitrogen (a), phosphorus (b) and potassium (c) of stevia during two growing seasons (2018-19). Ch-N chemical nitrogenous fertilizer, Org-N organic nitrogenous fertilizer, EM effective microorganisms. Each value expressed in figure is mean of two cuttings. Vertical bars indicate mean \pm standard deviation. Means followed by the same letter within the same series are not significantly different according to Fisher's least significant difference $(\mathrm{LSD})$ technique $(\mathrm{p} \leq 0.05)$

growing seasons, NFs and EM individually and when applied in combination increased the contents of available N, P and exchangeable $\mathrm{K}$ in the soil (Fig. 6).

\section{Discussion}

Nitrogen is the most difficult nutrient to manage in organic crop production (Aczel 2019). Cover crops and composts can provide a lot of $\mathrm{N}$ to plants, but synchronizing $\mathrm{N}$ release from these materials with plant

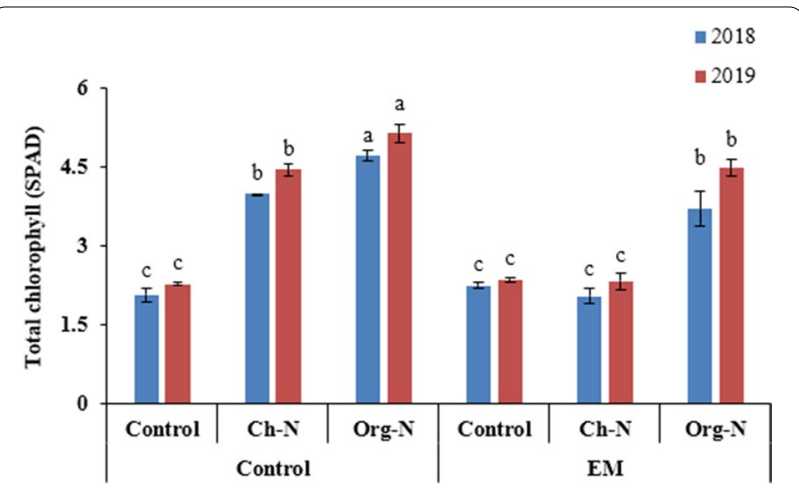

Fig. 3 Effect of different nitrogenous fertilizers and effective microorganisms on leaf chlorophyll contents of stevia during two growing seasons (2018-19). Ch-N chemical nitrogenous fertilizer, Org-N organic nitrogenous fertilizer, EM effective microorganisms. Each value expressed in figure is mean of two cuttings. Vertical bars indicate mean \pm standard deviation. Means followed by the same letter within the same series are not significantly different according to Fisher's least significant difference (LSD) technique $(p \leq 0.05)$
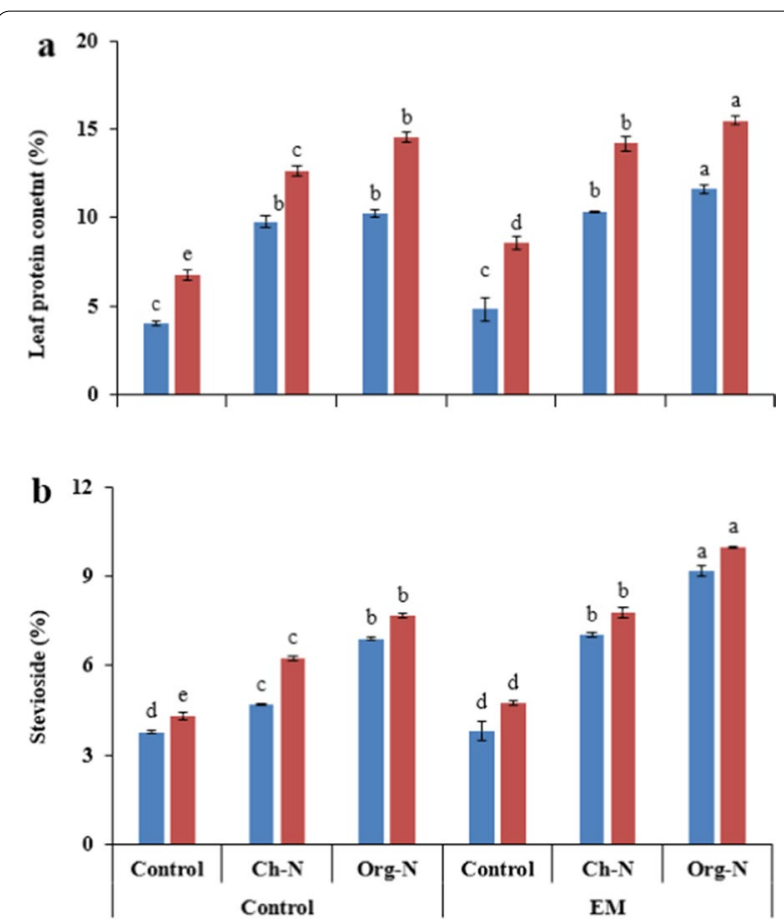

Fig. 4 Effect of different nitrogenous fertilizers and effective microorganisms on leaf protein (a) and stevioside (b) contents of stevia during two growing seasons (2018-19). Ch-N chemical nitrogenous fertilizer, Org-N organic nitrogenous fertilizer, EM effective microorganisms. Each value expressed in figure is mean of two cuttings. Vertical bars indicate mean \pm standard deviation. Means followed by the same letter within the same series are not significantly different according to Fisher's least significant difference (LSD) technique $(p \leq 0.05)$ 

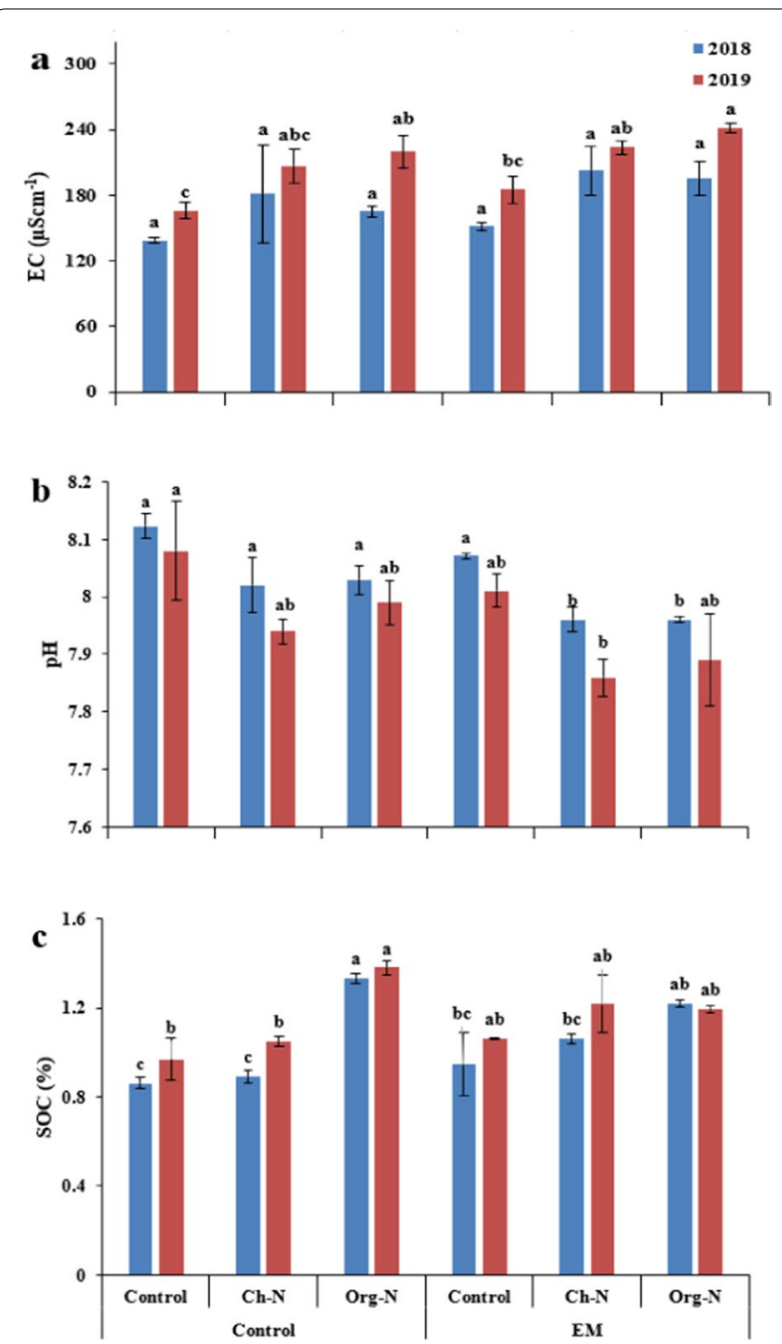

Fig. 5 Effect of nitrogenous fertilizers and effective microorganisms on electric conductivity (a), pH (b), and soil organic carbon (c) of soil after harvest during two growing seasons (2018-19). Ch-N chemical nitrogenous fertilizer, Org-N organic nitrogenous fertilizer, EM effective microorganisms. Each value expressed in figure is mean of two cuttings. Vertical bars indicate mean \pm standard deviation. Means followed by the same letter within the same series are not significantly different according to Fisher's least significant difference (LSD) technique $(p \leq 0.05)$

demand is difficult (Mikkelsen and Hartz 2008). For example, soy protein isolate can be used as a nitrogen amendment that is degraded in the soil without pretreatment (Olbrycht et al. 2020). Olbrycht et al. (2020) showed that the proteins diffuse slowly through the soil and are degraded simultaneously, which is accompanied by the release of ammonium ions. In another study, grain number per ear, thousand-grain weight, total yield, soluble sugar, starch, fat, protein and vitamin $C$ in maize were increased by the application of soybean protein hydrolysate modified with urea-formaldehyde
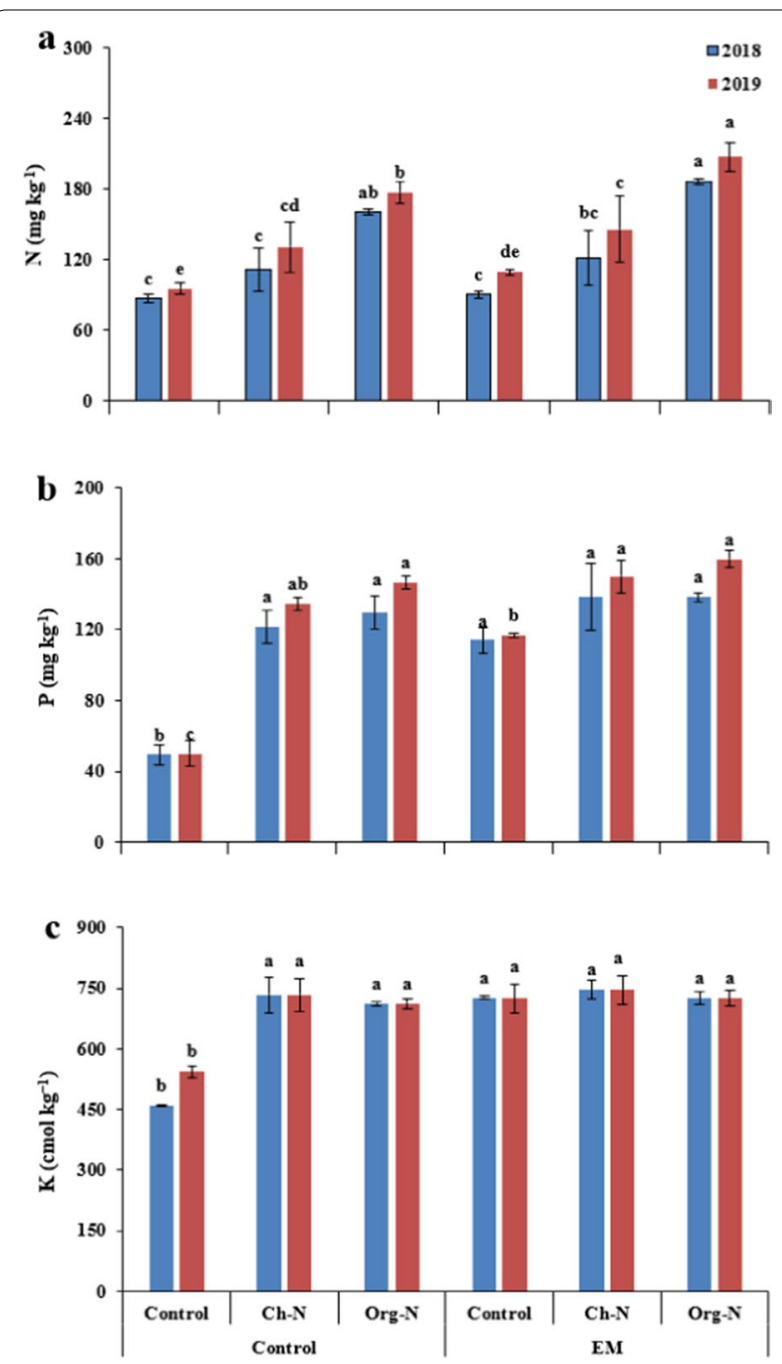

Fig. 6 Effect of nitrogenous fertilizers and effective microorganisms on available nitrogen (a), phosphorus (b), and potassium (c) of soil after harvest during two growing seasons (2018-19). Ch-N chemical nitrogenous fertilizer, Org-N organic nitrogenous fertilizer, EM effective microorganisms. Each value expressed in figure is mean of two cuttings. Vertical bars indicate mean \pm standard deviation. Means followed by the same letter within the same series are not significantly different according to Fisher's least significant difference $(\mathrm{LSD})$ technique $(p \leq 0.05)$

fertilizer compared to urea-formaldehyde and control (Liu et al. 2019).

The positive effects of Org-N with EM on growth variables of stevia plants may be attributed to the efficiency of microorganisms of the biofertilizer in immobilizing $\mathrm{N}$ in the form of $\mathrm{NH}_{4}^{+}$for a longer period of time, which promoted nutrient uptake by the plant ( $\mathrm{Di}$ and Cameron 2004). In a nursery experiment, Khan et al. (2006) discovered that EM had a positive effect on germination and seedling growth of Albizia saman in plants treated 
with different concentrations of EM solutions. Compared to untreated plants, EM treatments significantly increased vegetative growth, leaf chlorophyll content, and leaf mineral levels (N, P, K, Fe, Zn, and Mn) of apple trees (Cv. Anna) (Sahain et al. 2007). According to Olle et al. (2013) 70\% of publications reported a positive effect of EM on vegetable growth. Therefore, reasonable use of Org-N with EM can improve the growth characteristics and yield of the stevia. Our results are in corroboration with various studies reporting, and the increased growth characteristics were achieved due to the addition of organic nitrogen combined with biofertilizer by Das et al. (2008) and Liu et al. (2011) in stevia plant. It has also been reported earlier that organic nitrogenous fertilizers enhance plant growth and improves the yield of stevia by Chumthong and Detpiratmongkol (2016), quinoa by Geren (2015) and wheat by Guo et al. (2014). In this concern, Mohamed et al. (2012) showed that the application of Org-N with EM increased leaf N, P, and $\mathrm{K}$ contents of stevia plants, indicating a positive role of nitrogen in forming chlorophyll for the photosynthetic process (Tadesse 2019).

For dry leaf yield of stevia, incorporation of Org-N with EM was superior to all other treatments (Table 4). The promoting effect of this treatment on dry leaf yield could be due to a positive interaction resulting from increased SOC, soil structure and available nutrients after cultivation (Oldfield et al. 2019; Sheng-zhe et al. 2018). Oldfield et al. (2019) found that yields of maize and wheat crops were higher on average when the concentration of SOC was higher. These results are also in agreement with the findings of Zaman et al. (2015a) and Rashwan et al. (2017) in stevia plant, and Youssef (2016) in moringa plant.

The Ch-N along with EM significantly increased the P, $\mathrm{K}$ and chlorophyll contents of stevia. The reason might be the positive interaction of the combined application of $\mathrm{Ch}-\mathrm{N}$ and EM with improved properties of stevia. Yousef and co-workers discovered that the use of a combination of inorganic NPK and biofertilizer was most effective in enhancing growth, yield and nutrient accumulation in jew's mallow plants (Yousef et al. 2020). Similar results were reported by Das et al. (2007), Das et al. (2008), Liu et al. (2011), Kumar et al. (2013), and Enchev et al. (2018) in stevia plant.

The results showed that the content of stevioside in stevia leaves was significantly increased with the increase in biomass yield by applying Org-N along with EM. Stevioside accumulation in stevia leaf is the "mirror" to stevioside yield, which was considered as the final goal for every researcher (Hamad 2015). The combined application of Org- $\mathrm{N}$ and EM improved the vegetative growth of stevia, net photosynthetic ability, so that the photosynthetic product increased the amount of SOC and improved soil structure. Moreover, Chumthong and Detpiratmongkol (2016) found that the application of organic manure was suitable to increase different growth parameters of stevia and stevioside content in stevia leaves. Rashwan et al. (2017) found that the application of compost at 4.76 ton $\mathrm{ha}^{-1}+95 \mathrm{~kg} \mathrm{ha}^{-1} \mathrm{~N}$ as $\mathrm{NH}_{4} \mathrm{NO}_{3}$ with 3rd cutting was the best treatment for improving the yield and quality of stevia.

In this study, it was found that the combination of EM with Org-N or Ch-N fertilizer resulted in a significant reduction in soil $\mathrm{pH}$ compared to either EM or Org- $\mathrm{N}$ or $\mathrm{Ch}-\mathrm{N}$ treatment alone (Fig. 5). The difference in $\mathrm{pH}$ response to different fertilization regimes could be explained by one of two mechanisms. First, organic fertilization could have affected soil $\mathrm{pH}$ due to the liming effect of organic matter and carbonates of organic fertilizer (Cooper and Warman 1997). Second, ammonium can lower soil $\mathrm{pH}$ by completing the exchange sites of the soil solid phases with base cations ( $\mathrm{Li}$ et al. 1991). In addition, different fertilization regimes altered soil nutrient status to varying degrees in this study. EM with combined Org-N or Ch-N fertilizer applications as well as Org-N alone significantly improved SOC. We can attribute the improved SOC with organic fertilizer treatments to two mechanisms. Unlike other treatments, extracted soy protein has a high concentration of organic compounds that were readily biodegradable (Yanardağ et al. 2015). These results are in agreement with Yousef et al. (2020), who reported that the application of organic manure and its combination with biofertilizer increased the SOC at the end of the experimental period. In addition, organic manure could promote plant growth, resulting in increased input of SOC into the soil through the plants (Ding et al. 2012).

The results of the present study showed that the growth, yield and chemical composition of stevia plants were significantly affected by different nitrogenous fertilizers and effective microorganisms. Plant height, number of branches, fresh weight, dry weight, leaf area, dry leaf yield and stevioside content of stevia were found maximum under the influence of combined application of organic nitrogen and effective microorganisms. Soil properties like $\mathrm{pH}, \mathrm{EC}, \mathrm{SOC}$, available $\mathrm{N}, \mathrm{P}$ and exchangeable $\mathrm{K}$ content were also greatly improved by nitrogenous fertilizers and effective microorganisms. Considering all the parameters and treatments studied, it can be concluded that the application of organic nitrogen along with effective microorganisms is a promising approach to produce higher yield and improve the quality of stevia. Although the current study unfolded the performance ability of an isolated soybean protein as organic nitrogenous fertilizer to improving the productivity of the stevia crop, there is further need to understand the 
molecular mechanism behind it and improve the fertilization techniques and material according to the need for crops.

\section{Acknowledgements}

Thanks to all field technicians at College of Agriculture, Al-Azhar University branch Assiut, Egypt.

\section{Authors' contributions}

Conceptualization, MAY and AIA; methodology, MAY and AIA; statistical analysis, MMA, AFY, and SF; data curation, MAY and AIA; writing — original draft preparation, MMA and AFY; writing - review and editing MMA, WRS and HK. All authors read and approved the final manuscript.

\section{Funding}

This research received no external funding.

\section{Data availability statements}

All data available within the article.

\section{Declarations}

\section{Ethical approval and consent to participate}

This article does not contain any studies with human participants or animals performed by any of the authors.

\section{Consent for publication}

Not applicable.

\section{Competing interests}

The authors declare that they have no conflict of interest.

\section{Author details}

'Department of Soils and Water Sciences, Faculty of Agriculture, Al-Azhar University (Assiut Branch), Assiut 71524, Egypt. ${ }^{2}$ Department of Horticulture, College of Agriculture, University of Al-Azhar (Branch Assiut), Assiut 71524, Egypt. ${ }^{3}$ College of Horticulture, Fujian Agriculture and Forestry University, Fuzhou 350002, China. ${ }^{4}$ Agriculture Microbiology Department, Faculty of Agriculture, Beni-Suef University, Beni-Suef, Egypt. ${ }^{5}$ Plant Production Department, Faculty of Agriculture Saba Basha, Alexandria University, Alexandria 21531, Egypt. ${ }^{6}$ Institute of Technology and Life Sciences, Falenty, Al. Hrabska 3, 05-090 Raszyn, Poland. ${ }^{7}$ Department of Plant Physiology, Institute of Biology, Warsaw, University of Life Sciences SGGW, 159 Nowoursynowska 159, 02-776 Warsaw, Poland.

Received: 5 May 2021 Accepted: 18 September 2021 Published: 27 September 2021

\section{References}

Abdel-Gawad AM, Youssef MA (2019) Effects of soil application of different fertilizers and foliar spray with yeast extract on growth and yield of faba bean plants. Bull Fac Agric, Cairo Univ 70

Aczel MR (2019) What is the nitrogen cycle and why is it key to life? Front YouNg Minds 7(41):1-5. https://doi.org/10.3389/frym.2019.00041

Ahmad J, Khan I, Blundell R, Azzopardi J, Mahomoodally MF (2020) Stevia rebaudiana Bertoni.: an updated review of its health benefits, industrial applications and safety. Trends Food Sci Technol 100:177-189

Anbu S, Saranraj P (2016) Microbially fermented soybean meal as natural fertilizer: A. Approaches Int J Res Dev 10(1):2141-2151

Bargaz A, Lyamlouli K, Chtouki M, Zeroual Y, Dhiba D (2018) Soil microbial resources for improving fertilizers efficiency in an integrated plant nutrient management system. Front Microbiol 9:1606. https://doi.org/10. 3389/fmicb.2018.01606

Beck HE, Zimmermann NE, McVicar TR, Vergopolan N, Berg A, Wood EF (2018) Present and future Köppen-Geiger climate classification maps at 1-km resolution. Sci Data 5:180214. https://doi.org/10.1038/sdata.2018.214
Bulluck lii L, Ristaino J (2002) Effect of synthetic and organic soil fertility amendments on southern blight, soil microbial communities, and yield of processing tomatoes. Phytopathology 92(2):181-189. https://doi. org/10.1094/PHYTO.2002.92.2.181

Carter MR (1993) Soil sampling and methods of analysis. CRC Press, Taylor \& Francis Group United States of America, Boca Raton

Chumthong B, Detpiratmongkol S (2016) Effects of different types of manures and levels of applications on growth and yield of stevia (Stevia rebaudiana). J Agric Sci 12(7.1):1367-1373

Cooper J, Warman PR (1997) Effects of three fertility amendments on soil dehydrogenase activity, organic C and pH. Can J Soil Sci 77(2):281-283. https://doi.org/10.4141/S96-023

Das K, Dang R, Shivan TN, Sekeroglu N (2007) Influence of bio-fertilizers on the biomass yield and nutrient content in Stevia rebaudiana Bert. grown in Indian subtropics. J Med Plant Res 1(1):005-008. https://doi. org/10.5897/JMPR.9000788

Das K, Dang R, Shivananda T (2008) Influence of bio-fertilizers on the availability of nutrients (N, P and K) in soil in relation to growth and yield of Stevia rebaudiana grown in South India. Int J Appl Res Nat Prod 1(1):1-15

Debnath M (2007) Clonal propagation and antimicrobial activity of an endemic medicinal plant Stevia rebaudiana. J Med Plant Res 2(2):045051. https://doi.org/10.5897/JMPR.9000368

Di H, Cameron KC (2004) Effects of the nitrification inhibitor dicyandiamide on potassium, magnesium and calcium leaching in grazed grassland. Soil Use Manag 20(1):2-7. https://doi.org/10.1111/j.1475-2743.2004. tb00330.x

Ding X, Han X, Liang Y, Qiao Y, Li L, Li N (2012) Changes in soil organic carbon pools after 10 years of continuous manuring combined with chemical fertilizer in a Mollisol in China. Soil Tillage Res 122:36-41. https://doi.org/ 10.1016/..still.2012.02.002

Ei-Slirafy Z, Hassan R, El-Slhazly M, Gad M (2015) Role of bio and organic fertilizers in reducing some chemical fertilizers doses on yield of stevia plants under some different soil types. J Soil Sci Agric Eng 6(7):829-844. https:// doi.org/10.21608/JSSAE.2015.42776

El-Hoseiny HM, Helaly MN, Elsheery NI, Alam-Eldein SM (2020) Humic acid and boron to minimize the incidence of alternate bearing and improve the productivity and fruit quality of mango trees. HortScience 55(7):1026-1037

Elsheery NI, Helaly MN, El-Hoseiny HM, Alam-Eldein SM (2020a) Zinc oxide and silicone nanoparticles to improve the resistance mechanism and annual productivity of salt-stressed mango trees. Agronomy 10(4):558

Elsheery NI, Sunoj V, Wen Y, Zhu J, Muralidharan G, Cao K (2020b) Foliar application of nanoparticles mitigates the chilling effect on photosynthesis and photoprotection in sugarcane. Plant Physiol Biochem 149:50-60

Enchev S, Mehmed A, Kikindonov G (2018) Effect of mineral and organic fertilization on the production of Stevia (Stevia rebauduana B.). Bulg J Agric Sci 24(Suppl. 2):100-103

Geren H (2015) Effects of different nitrogen levels on the grain yield and some yield components of quinoa (Chenopodium quinoa Willd.) under Mediterranean climatic conditions. Turkish J Field Crop 20(1):59-64. https://doi. org/10.17557/39586

Ghanta S, Banerjee A, Poddar A, Chattopadhyay S (2007) Oxidative DNA damage preventive activity and antioxidant potential of Stevia rebaudiana Bertoni, a natural sweetener. J Agric Food Chem 55(26):10962-10967. https://doi.org/10.1021/jf071892q

Guo C, Guo L, Li X, Gu J, Zhao M, Duan W, Ma C, Lu W, Xiao K (2014) TaPT2, a high-affinity phosphate transporter gene in wheat (Triticum aestivum L.), is crucial in plant Pi uptake under phosphorus deprivation. Acta Physiol Plant 36(6):1373-1384. https://doi.org/10.1007/s11738-014-1516-x

Hamad A (2015) Productivity of Stevia rebaudiana bertoni plant and its effective by salinity, nitrogen and potassium fertilization. Int J Plant Prod 6(9):1543-1552. https://doi.org/10.21608/JPP.2015.52018

Hardjowigeno S (2007) IImu tanah [Soil science], Jakarta

Hasnain M, Chen J, Ahmed N, Memon S, Wang L, Wang Y, Wang P (2020) The effects of fertilizer type and application time on soil properties, plant traits. Yield Qual Tomato Sustain 12(21):9065. https://doi.org/10.3390/ su12219065

Huda M, Ahmed A, Mandal C, Alam KA, Reza S, Wadud A (2007) In vitro morphogenic responses of different explants of Stevia (Stevia rebaudiana Bert). Int J Agr Res 12:1006-1013 
Khan B, Hossain M, Mridha M (2006) Effect of microbial inoculants on Albizia saman germination and seedling growth. J for Res 17(2):99-102. https:// doi.org/10.1007/s11676-006-0023-3

Kumar R, Sharma S, Prasad R (2013) Yield, nutrient uptake, and quality of stevia as affected by organic sources of nutrient. Commun Soil Sci Plant Anal 44(21):3137-3149. https://doi.org/10.1080/00103624.2013.832285

Leghari SJ, Wahocho NA, Laghari GM, HafeezLaghari A, MustafaBhabhan G, HussainTalpur K, Bhutto TA, Wahocho SA, Lashari AA (2016) Role of nitrogen for plant growth and development: a review. Adv Environ Biol 10(9):209-219

Lemus-Mondaca R, Vega-Gálvez A, Zura-Bravo L, Ah-Hen K (2012) Stevia rebaudiana Bertoni, source of a high-potency natural sweetener: a comprehensive review on the biochemical, nutritional and functional aspects. Food Chem 132(3):1121-1132. https://doi.org/10.1016/j.foodchem.2011.11.140

Li XL, George E, Marschner H (1991) Phosphorus depletion and pH decrease at the root-soil and hyphae-soil interfaces of VA mycorrhizal white clover fertilized with ammonium. N Phytol 119(3):397-404. https://doi.org/10. 1111/j.1469-8137.1991.tb00039.x

Liu X, Ren G, Shi Y (2011) The effect of organic manure and chemical fertilizer on growth and development of Stevia rebaudiana Bertoni. Energy Procedia 5:1200-1204. https://doi.org/10.1016/j.egypro.2011.03.210

Liu N, Qu P, Huang H, Wei Z (2019) Soybean protein hydrolysate-formaldehyde-urea block copolymer for controlled release fertilizer. Env Pollut Bioavil 31(1):94-102. https://doi.org/10.1080/26395940.2019.1589389

Madejón P, Marañón T, Murillo JM (2006) Biomonitoring of trace elements in the leaves and fruits of wild olive and holm oak trees. Sci Total Environ 355(1-3):187-203. https://doi.org/10.1016/j.scitotenv.2005.02.028

Mariotti F, Tomé D, Mirand PP (2008) Converting nitrogen into proteinbeyond 6.25 and Jones' factors. Crit Rev Food Sci Nutr 48(2):177-184. https://doi.org/10.1080/10408390701279749

Meena VS, Maurya B, Verma JP (2014) Does a rhizospheric microorganism enhance K+ availability in agricultural soils? Microbiol Res 169(5-6):337347. https://doi.org/10.1016/j.micres.2013.09.003

Mikkelsen R, Hartz T (2008) Nitrogen sources for organic crop production. Better Crops 92(4):16-19

Mohamed S, El-Ghait E, Youssef A, Khalil A, Attia K (2012) Effect of irrigation rate and some fertilization treatments on vegetative growth and chemical composition of Stevia rebaudiana. Annals of Agric Sci, Moshtohor 50(4):435-446

Motsara M, Roy RN (2008) Guide to laboratory establishment for plant nutrient analysis, vol 19. Food and Agriculture Organization of the United Nations Rome

Naser HM, Hanan E-H, Elsheery NI, Kalaji HM (2016) Effect of biofertilizers and putrescine amine on the physiological features and productivity of date palm (Phoenix dactylifera, L.) grown on reclaimed-salinized soil. Trees 30(4):1149-1161

Nishiyama P, Alvarez M, Vieira LG (1992) Quantitative analysis of stevioside in the leaves of Stevia rebaudiana by near infrared reflectance spectroscopy. J Sci Food Agric 59(3):277-281. https://doi.org/10.1002/jsfa.2740590302

Olbrycht M, Kołodziej M, Bochenek R, Przywara M, Balawejder M, Matłok N, Antos P, Piątkowski W, Antos D (2020) Mechanism of nutrition activity of a microgranule fertilizer fortified with proteins. BMC Plant Biol 20:1-12. https://doi.org/10.1186/s12870-020-02340-4

Oldfield EE, Bradford MA, Wood SA (2019) Global meta-analysis of the relationship between soil organic matter and crop yields. Soil 5(1):15-32. https:// doi.org/10.5194/soil-5-15-2019

Olle M, Williams IH (2013) Effective microorganisms and their influence on vegetable production-a review. J Hortic Sci Biotechnol 88(4):380-386. https://doi.org/10.1080/14620316.2013.11512979

Pandey S, Singh H (2011) A simple, cost-effective method for leaf area estimation. J Bot. https://doi.org/10.1155/2011/658240

Patil N (2010) Biofertilizer effect on growth, protein and carbohydrate content in Stevia rebaudiana var Bertoni. Recent Res Sci Technol 2(10):42-44 https://doi.org/10.1016/j.chroma.2006.09.008

Pól J, Hohnová B, Hyötyläinen T (2007) Characterisation of Stevia rebaudiana by comprehensive two-dimensional liquid chromatography time-of-flight mass spectrometry. J Chromatogr A 1150(1-2):85-92. https://doi.org/10. 1016/j.chroma.2006.09.008
Rajasekaran S, Sundaramoorthy P, Sankar Ganesh K (2015) Effect of FYM, N, P fertilizers and biofertilizers on germination and growth of paddy (Oryza sativa L.). Int Lett Nat Sci 8:59-65

Rashwan BR, Abd-El Raouf RM, Ahmed NR, Ferweez H (2017) Efficacy of K-Humate, compost and biofertilizer application as well as cutting number on yield and quality of stevia (Stevia rebaudiana Bertoni) as natural sweetener. Assiut J Agric Sci 48(1):251-268

Rios J-L, Recio MC (2005) Medicinal plants and antimicrobial activity. J Ethnopharmacol 100(1-2):80-84. https://doi.org/10.1016/j.jep.2005.04.025

Sahain MF, El-Motty E, El-Shiekh MH, Hagagg LF (2007) Effect of some biostimulant on growth and fruiting of Anna apple trees in newly reclaimed areas. J Agric Biol Sci 3(5):422-429

Saraswati R, Sumarno D (2008) Application of soil microorganisms as component of agriculture technology. Iptek Tan Pangan 3(1):41-58

Savci S (2012) Investigation of effect of chemical fertilizers on environment. APCBEE Proc 1:287-292. https://doi.org/10.1016/j.apcbee.2012.03.047

Sedlacek CJ, Giguere AT, Pjevac P (2020) Is too much fertilizer a problem? Front Young Minds 8(63):1-5. https://doi.org/10.3389/frym.2020.00063

Shalini R, Gupta D (2010) Utilization of pomace from apple processing industries: a review. J Food Sci Technol 47(4):365-371. https://doi.org/10.1007/ s13197-010-0061-x

Sheng-zhe E, Ning-ping DI, Li-li LI, Jin-hua YU, Zong-xian CH, Hai-yan ZH, Lai-gui SH (2018) Relationship of crop yield and soil organic carbon and nitrogen under long-term fertilization in black loessial soil region on the Loess Plateau in China. Yingyong Shengtai Xuebao 29(12):4047-4055

Sorgonà A, Abenavoli MR, Cacco G, Gelsomino AJCs, (2011) Growth of tomato and zucchini seedlings in orange waste compost media: $\mathrm{pH}$ and implication of dosage. Compost Sci Util 19(3):189-196. https://doi.org/10.1080/ $1065657 \times .2011 .10736999$

Tadesse N (2019) The response of stevia (Stevia rebaudiana L.) to nitrogen and phosphorous fertilizer rates at Menagesha, West Ethiopia. J Environ Sci Nat Resour 22(3):01-05

Yakhin OI, Lubyanov AA, Yakhin IA, Brown PH (2017) Biostimulants in plant science: a global perspective. Front Plant Sci 7:2049

Yanardağ İH, Zornoza R, Cano AF, Yanardağ AB, Mermut A (2015) Evaluation of carbon and nitrogen dynamics in different soil types amended with pig slurry, pig manure and its biochar by chemical and thermogravimetric analysis. Biol Fertil Soils 51(2):183-196. https://doi.org/10.1007/ s00374-014-0962-3

Yang J, Liu X, Shi Y (2013) Effect of different mixed fertilizer on yield, quality and economic benefits in Stevia rebaudiana Bertoni. Adv J Food Sci Technol 5(5):588-591

Yousef AF, Youssef MA, Ali MM, Ibrahim MM, Xu Y, Mauro RP (2020) Improved growth and yield response of jew's mallow (Corchorus olitorius L.) plants through biofertilization under semi-arid climate conditions in Egypt. Agronomy 10(11):1801. https://doi.org/10.3390/agronomy10111801

Youssef MA (2016) Impact of biofertilizers on growth and yield of (Moringa Oleifera Lam) plants. Al-Azhar J Agric Res 26:127-138

Zaman M, Chowdhury M, Chowdhury T (2015a) Growth parameters and leaf biomass yield of stevia (Stevia rebaudiana, Bertoni) as influenced by different soil types of Bangladesh. J Bangladesh Agril Univ 13(1):31-37. https:// doi.org/10.22004/ag.econ.235278

Zaman M, Chowdhury M, Chowdhury T (2015b) Integrated effects of poultry manure and chemical fertilizer on the growth, leaf yield and stevioside content of stevia. J Bangladesh Agril Univ 13:173-182

Zaman M, Chowdhury M, Islam M, Uddin M (2015c) Effects of vermicompost on growth and leaf biomass yield of stevia and post harvest fertility status of soil. J Bangladesh Agril Univ 13(2):169-174

Zhou Y-h, Zhang Y-I, Wang X-m, Cui J-x, Xia X-j, Shi K, Yu J-q (2011) Effects of nitrogen form on growth, $\mathrm{CO}_{2}$ assimilation, chlorophyll fluorescence, and photosynthetic electron allocation in cucumber and rice plants. J Zhejiang Univ Sci B 12(2):126-134. https://doi.org/10.1631/jzus.B1000059

\section{Publisher's Note}

Springer Nature remains neutral with regard to jurisdictional claims in published maps and institutional affiliations. 